\title{
PERBANDINGAN KINERJA DENGAN BALANCE SCORECARD PERSPEKTIF KEUANGAN PADA BANK SYARIAH BUMN DI INDONESIA
}

\author{
Reka Meilani \\ STAIN Syaikh Abdurrahman Siddik Bangka Belitung
}

\begin{abstract}
The aims of study were to know and analyze the performance of Bank Syariah BUMN in Indonesia seen in the concept of Balance Scorecard, especially financial perspective and compare financial performance. This study was a descriptive study that explains a picture of a particular object and result. This study described the performance appraisal results from the financial perspective of Bank Syariah Mandiri, BNI Syariah, BRI Syariah in 2016. The type of data used in this study were secondary data in the form of financial data of Bank Syariah Mandiri, BNI Syariah, BRI Syariah, which has been published year 2016. The data source is obtained from Indonesian Banking Directory published by Bank Indonesia, from the Indonesia Stock Exchange website. Methods of data analysis used descriptive analysis. Based on the performance analysis of Balancae Score Card with financial perspective, it can be concluded that BRI Syariah, BNI Syariah and Bank Mandiri Syariah has a good performance in 2016. Capital ratio, Earning Assets Quality (KAP) Ratio, Profitability Ratio (earnings), Liquidity Ratio (liquidity) and Sensitivity to market risk in BRI Syariah pertained good. Capital Ratio (Capital), Earning Asset Quality (KAP) Ratios, Profitability Ratio (earnings), Liquidity Ratio (liquidity) and Sensitivity to Market Risk (BNI Syariah) were good. Capital Ratio (Capital), Earning Asset Quality (KAP) Ratios, Profitability Ratios (earnings), Liquidity Ratio (liquidity) and Sensitivity to market risk in Bank Syariah Mandiri were good. Based on the comparison of capital ratio, earning asset ratio, liquidity ratio and sensitivity to market risk in Bank Syariah Mandiri, BNI Syariah and
\end{abstract}


BRI Syariah, in general the largest ratio were the ratio of BRI Syariah except capital ratio, both BNI Syariah except liquidity ratio and except market sensitivity. Keywords: Bank Syariah, Balance Scorecard, performance, financial perspective

\section{A. Latar Belakang}

Pengukuran kinerja perusahaan penting dilakukan baik oleh manajemen, pemegang saham, pemerintah dan pihak lain yang berkepentingan dan terkait dengan distribusi kesejahteraan di antaranya bidang perbankan. Pengukuran kinerja dengan ukuran rasio keuangan yang digunakan sebagai indikator pengukuran kinerja perusahaan saat ini hanya merupakan pendekatan akuntansi saja dan penggunaan banyak mengandung kelemahan yaitu pengukuran tidak mencerminkan keadaan sebenarnya dan laporan dibuat untuk kepentingannya tanpa memperhatikan stakeholder lain, sehingga laporan keuangan direkayasa untuk mendapatkan rasio yang baik pada momen tertentu saja. Hal ini menyebabkan semakin banyak gugatan terhadap laporan keuangan khususnya bila dipakai sebagai indikator pengukuran kinerja perusahaan.

Adanya persaingan antar bank syariah maupun dengan bank konvensional, membuat bank syariah dituntut untuk memiliki kinerja yang bagus agar dapat bersaing dalam memperebutkan pasar perbankan nasional di Indonesia. Selain itu BI juga semakin memperketat dalam pengaturan dan pengawasan perbankan nasional. Karena BI tidak ingin mengulangi peristiwa di awal krisis ekonomi pada tahun 1997 dimana banyak bank dilikuidasi karena kinerjanya tidak sehat, yang pada akhirnya merugikan masyarakat. Salah satu penilaian kinerja yang dapat dilakukan adalah dengan menilai kinerja keuangan untuk mengetahui tingkat kesehatan bank. Karena kinerja keuangan dapat menunjukkan kualitas bank melalui penghitungan rasio keuangannya. Untuk menghitung rasio keuangan dapat dilakukan dengan menganalisis laporan keuangan bank yang dipublikasikan secara berkala. 
Perkembangan sistem perbankan syariah di Indonesia dalam dua dekade pengembangan keuangan syariah nasional, sudah banyak pencapaian kemajuan, baik dari aspek lembaga dan infrastruktur penunjang, perangkat regulasi dan sistem pengawasan, maupun awareness dan literasi masyarakat terhadap layanan jasa keuangan syariah. Setelah mengalami pertumbuhan yang relatif tinggi pada tahun- tahun sebelumnya, ditahun 2015-2016 perbankan syariah menghadapi tantangan berupa perlambatan pertumbuhan. Kondisi permodalan yang terbatas merupakan faktor penting yang mempengaruhi rendahnya ekspansi aset perbankan syariah. Saat ini dari 12 bank umum syariah (BUS), sepuluh BUS memiliki modal inti kurang dari Rp2 Triliun, serta belum ada BUS yang memiliki modal inti melebihi Rp5 Triliun. Hal ini menyebabkan bank-bank syariah menjadi kurang leluasa untuk membuka kantor cabang, mengembangkan infrastruktur, dan mengembangkan segmen layanan ${ }^{1}$. Berdasarkan perkembangan sektor jasa keuangan syariah menunjukkan Capital Adequeacy Ratio (CAR) perbankan syariah mengalami penurunan dimana pada Desember 2015 sebesar 15,74 persen menjadi14,96 persen pada Oktober 2016 turun -0,78 persen seperti Tabel 1 berikut.

Tabel 1. Perkembangan Bank Syariah di Indonesia

\begin{tabular}{lccc}
\hline \multicolumn{1}{c}{ Indikator Utama } & $\begin{array}{c}\text { Desember } \\
\text { nnic }\end{array}$ & $\begin{array}{c}\text { Oktober } \\
\text { nnc }\end{array}$ & \% Pertumbuhan \\
\hline BUS+UUS & 272,34 & 276,6 & $1,56 \%$ \\
Total Aset & & & \\
DPK & 217,86 & 219,48 & $0,74 \%$ \\
Pembiayaan & 199,33 & 207,77 & $4,23 \%$ \\
CAR \% & 15,74 & 14,96 & $-0,78 \%$ \\
NPF Gross (\%) & 4,33 & 4,74 & $0,41 \%$ \\
ROA (\%) & 0,85 & 0,96 & $0,11 \%$ \\
FDR (\%) & 91,50 & 94,66 & $3,16 \%$ \\
\hline
\end{tabular}

Sumber: www.ojk.go.id, Tahun 2015-2016

${ }^{1}$ www.ojk.go.id diakses tanggal 4 Agustus 2017 
Evaluasi kinerja memerlukan suatu standar pengukuran kinerja yang tepat, dalam arti tidak hanya berorientasi pada sektor keuangan saja, karena hal tersebut sangat kurang tepat dalam menghadapi persaingan bisnis yang semakin ketat.Oleh karena itu perlu dilengkapi dengan informasi dari sektor non keuangan, seperti kepuasan konsumen, kualitas produk atau jasa, loyalitas karyawan dan sebagainya, sehingga pihak manajemen perusahaan dapat mengambil keputusan yang tepat untuk kepentingan hidup perusahaandalam jangka panjang.

Ada beberapa metode yang dapat digunakan untuk mengukur kinerja bank syariah dan salah satunya alat analisis dalam akuntansi manajemen yang bertujuan untuk menunjang proses manajemen yang disebut dengan Balanced Scorecard yang dikembangkan oleh Norton pada tahun 1990. Balanced Scorecard merupakan suatu ukuran yang cukup komprehensif dalam mewujudkan kinerja, yang mana keberhasilan keuangan yang dicapai perusahaan bersifat jangka panjang. Balanced Scorecard tidak hanya sekedar alat pengukur kinerja perusahaan tetapi merupakan suatu bentuk transformasi strategik secara total kepada seluruh tingkatan dalam organisasi. Dengan pengukuran kinerja yang komprehensif tidak hanya merupakan ukuran-ukuran keuangan tetapi penggabungan ukuran-ukuran keuangan dan non keuangan, maka perusahaan dapat menjalankan bisnisnya dengan lebih baik.

Balanced Scorecard merupakan suatu konsep manajemen kontemporer yang dapat digunakan sebagai alat untuk menilai kinerja. Pengukuran kinerja ini dilakukan dengan komprehensif, terukur dan berimbang dengan melihat dari perspektif keuangan, pelanggan, proses bisnis internal dan pembelajaran dan pertumbuhan. Pengukuran kinerja ini dilakukan dengan komprehensif, terukur dan berimbang dengan melihat dari perspektif keuangan, pelanggan, proses bisnis internal dan pembelajarandan pertumbuhan. ${ }^{2}$ Berdasarkan latar

${ }^{2}$ Istiqlal, Chayo Halim. 2009. Penilaian Kinerja Perbankan Syariah Dengan Metode Balanced Scorecard. Jurnal Ekonomi Islam, Volume 2, Desember. hal. 1 
belakang diatas, diperlukan adanya penelitian untuk menilai kinerja perbankan syariah dengan menggunakan pendekatan yang lebih komprehensif.

Adapun alasan peneliti memilih studi kasus pada Bank Syariah Milik BUMN dikarenakan adanya isu mengenai holding (pemergeran) bank syariah milik BUMN. Pemergeran dilakukan karena faktor modal bank-bank syariah tersebut masih minim. Padahal bank-bank syariah milik BUMN yang terdiri dari Bank Mandiri Syariah, BRI Syariah dan BNI Syariah tersebut mempunyai pangsa pasar yang besar dalam perbankan syariah. Tujuan penelitian ini antara lain untuk mengetahui dan menganalisis kinerja Bank Syariah BUMN di Indonesia dilihat dalam konsep Balance Scorecard khususnya perspektif keuangan serta membandingkan kinerja keuangannya.

\section{B. Landasan Teori dan Hipotesis}

\section{Bank Syariah}

Bank syariah adalah bank yang beroperasi dengan tidak mengandalkan sistem bunga, sehingga bank syariah juga sering disebut interest free bank atau bank tanpa bunga. ${ }^{3}$ Bank syariah merupakan lembaga keuangan yang beroperasi dengan sistem operasional dan produk yang dikembangkan berdasarkan Al-Qur'an dan Al-Hadist. Bank berdasarkan prinsip syariah adalah aturan perjanjian berdasarkan hukum Islam antara bank dengan pihak lain untuk menyimpan dana atau pembiayaan usaha atau kegiatan perbankan lainnya. ${ }^{4}$ Bank berdasarkan prinsip syariah mengharamkan penggunaan harga produknya dengan bunga tertentu karena bunga adalah riba.

Sedangkan pengertian syariah adalah sebutan bagi peraturan dan hukum yang ditetapkan Allah SWT atau ditetapkan prinsip-prinsipnya, lalu

\footnotetext{
${ }^{3}$ Antonio, Muhammad Syafi'i. 2005. Bank Syariah: Wacana Ulama dan Cendekiawan. Jakarta: Bank Indonesia. Hal. 1

${ }^{4}$ Kasmir. 2004. Bank dan Lembaga Keuangan Lainnya. Jakarta: PT Raja Grafindo Persada. hal. 24
} 
diwajibkan-Nya kepada kaum muslimin agar berpegang teguh pada ketentuan tersebut dalam melakukan kegiatan sehari-hari dalam berhubungan dengan Allah SWT dan manusia. Dalam melaksanakan perbankan yang berlandaskan syariah harus diawali dengan niat karena amal baik dan buruk sangat tergantung pada niat yang diwujudkan dalam bentuk ketentuan perikatan (akad) sesuai hukum syariah Islam.

Bank syariah mempunyai dua peran utama, yaitu sebagai badan usaha (tamwil) dan badan sosial (maal). Sebagai badan usaha, bank syariah mempunyai beberapa fungsi sebagai manajer investasi, investor dan penyedia jasa perbankan: ${ }^{5}$

a. Sebagai manajer investasi yang dapat mengelola investasi atas dana nasabah dengan menggunakan akad mudharabah atau sebagai agen investasi.

b. Sebagai investor yang menginvestasikan dana yang dimiliki maupun dana nasabah dengan menggunakan alat investasi yang sesuai dengan syariah.

c. Sebagai penyedia jasa keuangan dan lalu lintas pembayaran sepanjang tidak bertentangan dengan syariah.

Sedangkan sebagai badan sosial, bank syariah mempunyai fungsi sebagai pengelola dan sosial untuk penghimpunan dan penyaluran zakat, infak dan sedekah serta penyaluran qardhul hasan (pinjaman kebajikan).

\section{Kinerja dengan Balance Scorecard}

Penilaian kinerja adalah penentuan secara periodik efektitas operasional suatu organisasi, bagian organisasi dan karyawannya berdasarkan sasaran, dan

${ }^{5}$ Ascarya. 2005. Akad dan Produk Bank Syariah. Jakarta: PT Raja Grafindo Persada. hal. 13 
standar yang telah ditetapkan sebelumnya. ${ }^{6}$ Kinerja perusahaan merupakan sesuatu yang dihasilkan oleh suatu perusahaan dalam periode tertentu dengan mengacu pada standar yang ditetapkan. Kinerja perusahaan hendaknya merupakan hasil yang dapat diukur dan menggambarkan kondisi empirik suatu perusahaan dari berbagai ukuran yang disepakati. Untuk mengetahui kinerja yang dicapai maka dilakukan penilaian kinerja. ${ }^{7}$ Kata penilaian sering diartikan dengan kata assessment. Sedangkan kinerja perusahaan merupakan sesuatu yang dihasilkan oleh suatu perusahaan dalam periode tertentu dengan mengacu pada standar yang ditetapkan. Dengan demikian penilaian kinerja perusahaan (Companies performance assessment) mengandung makna suatu proses atau sistem penilaian mengenai pelaksanaan kemampuan kerja suatu perusahaan (organisasi) berdasarkan standar tertentu.

Hansen dan Mowen membedakan penilaian kinerja secara tradisional dan kontemporer. Penilaian kinerja tradisional dilakukan dengan membandingkan kinerja actual dan kinerja yang telah dianggarkan atau biaya standar sesuai dengan karakteristik pertanggung jawabannya. ${ }^{8}$ Sedangkan penilaian kontemporer menggunakan aktivitas sebagai pondasinya. Ukuran kinerja dirancang menilai seberapa baik aktivitas dilakukan dan dapat mengidentikasi apakah telah dilakukan perbaikan yang berkesinambungan. Salah satu perspektif dalam Balance Scorecard.

\subsection{Perspektif Keuangan}

Perspektif keuangan tetap menjadi perhatian, karena ukuran keuangan merupakan suatu ikhtisar dari konsekuensi ekonomi yang terjadi yang disebabkan oleh keputusan dan tindakan ekonomi yang diambil. Pengukuran

${ }^{6}$ Istiqlal, Chayo Halim. 2009. Penilaian Kinerja Perbankan Syariah Dengan Metode Balanced Scorecard. Jurnal Ekonomi Islam, Volume 2 Desember, hal. 5

${ }^{7}$ Ibid. hal. 6

${ }^{8}$ Ibid. hal. 7 
kinerja keuangan menunjukkan apakah perencanaan, implementasi dan pelaksanaan strategi memberikan perbaikan yang mendasar. Perbaikan-perbaikan ini tercermin dalam sasaran-sasaran yang secara khusus berhubungan dengan keuntungan yang terukur dengan baik.

Balance Scorecard mengakomodasi perspektif keuangan sebagai ukuran kinerja yang menggambarkan ikhtisar dari konsekuensi ekonomis atas setiap tindakan dan keputusan yang diambil. ${ }^{9}$ Kinerja perspektif keuangan yang diteliti terdiri dari rasio-rasio keuangan yang sesuai dari laporan keuangan, yaitu: 10

\section{a. Aktiva Produktif}

Aktiva produktif merupakan semua aktiva dalam rupiah dan valuta asing yang dimiliki bank dengan maksud untuk memperoleh penghasilan sesuai dengan fungsinya.Untuk mengukur aktiva produktif bermasalah bank dapat digunakan Non-Performing Loans dan Non-PerformingFinancing.

b. Rasio Efisiensi (Rasio Biaya Operasional)

Rasio biaya operasional adalah perbandingan antara biaya operasional dan pendapatan operasional. Rasio ini digunakan untuk mengukur tingkat efisiensi dan kemampuan bank dalam melakukan kegiatan operasinya.

c. Rasio Likuiditas

Likuiditas merupakan teknik untuk mengukur risiko ketidakmampuan bank memenuhi kebutuhan-kebutuhan likuiditas yang segera harus dipenuhi. Pengukuran likuiditas dalam penelitian ini menggunakan Loan to Deposit Ratio.

${ }^{9}$ Mulyadi. 2001. Balance Scorecard: Alat Manajemen Kontemporer untuk Pelipatganda Kinerja Keuangan Perusahaan. Jakarta: Salemba Empat. Hal.35.

${ }^{10}$ Rhamadana, R. 2016. Analisis Rasio Keuangan Untuk Menilai Kinerja. Journal STESIA. Volume 6, No.2, hal.2. 
Berdasarkan tahap-tahap perkembangan industri tersebut akan diperlukan strategi-strategi yang berbeda-beda. Dalam perspektif keuangan, terdapat tiga aspek dari strategi yang dilakukan suatu perusahaan. Pertama, pertumbuhan pendapatan dan kombinasi pendapatan yang dimiliki suatu organisasi bisnis. Kedua, penurunan biaya dan peningkatan produktivitas. Ketiga adalah penggunaan aset yang optimal dan strategi investasi. Sasaransasaran perspektif keuangan dibedakan pada masing-masing tahap siklus bisnis dibedakan menjadi: ${ }^{11}$

a. Growth (Perkembangan)

Growth merupakan tahap pertama dan tahap awal dari sikluskehidupan bisnis. Pada tahap ini perusahaan memiliki tingkat pertumbuhan yang sama sekali atau paling tidak memiliki potensi untuk berkembang. Untuk menciptakan potensi ini, kemungkinan seorang manajer harus terikat komitmen untuk mengembangkan suatu produkatau jasa baru, membangun dan mengembangkan fasilitas produksi, menambah kemampuan operasi, mengembangkan sistem infrastruktur dan jaringan distribusi yang akan mendukung hubungan global. Sasarankeuangan dari bisnis pada tahap ini seharusnya menekankanpengukuran pada tingkat pertumbuhan revenue atau penjualan dalam pasar yang ditergetkan.

b. Sustain Stage (Bertahan)

Sustain stage merupakan tahap kedua, yaitu suatu tahap dimana perusahaan masih melakukan investasi dan reinvestasi dengan mempersyaratkan tingkat pengembalian yang terbaik. Dalam tahap ini, perusahaan berusaha mempertahankan pangsa pasar yang ada dan mengembangkannya apabila mungkin.Secara konsisten pada tahap ini perusahaan tidak lagi bertumpu pada strategi jangka panjang.Sasaran

${ }^{11}$ Kaplan, Robbert S. dan David P. Norton. 2001. The Strategy Focused Organizations: How Balanced Scorecard Companies Thrive in The New Business Environment. Boston: Harvard Business School Press. hal. 65. 
keuangan pada tahap ini lebih diarahkan pada besarnya tingkat pengembalian atas investasi yang dilakukan.

c. Harvest (Panen)

Tahap ini merupakan tahap kematangan (mature), suatu tahap dimana perusahaan melakukan panen (harvest) terhadap investasi mereka. Perusahaan tidak melakukan investasi lebih jauh kecuali hanya untuk memelihara perbaikan fasilitas, tidak untuk melakukan ekspansi atau membangun suatu kemampuan baru.

Kebijaksanaan keuangan untuk ketiga tahap tersebut akan berbeda sekali. Sasaran keuangan untuk growth stage akan menekankan pada pertumbuhan penjualan di pasar baru dari konsumen baruatau dari produk dan jasa baru. Sasaran dalam sustain stage lebih menekankan pada pengukuran kinerja tradisional sepeti ROI. Semua ukuran ini menggambarkan sasaran keuangan klasik yaitu memperoleh tingkat pengembalian terbaik atas modal yang ditanam dalam bisnis. Sasaran keuangan untuk harvest stage adalah cash flow. Pengukuran kinerja keuangan tradisional seperti ROI kurang relevan digunakan pada tahap ini, karena investasi utama telah dilakukan.Sasaran pengukuran pada tahap ini bukan lagi pada ROI maksimum, tetapi pada cash flow maksimum yang mampu dikembalikan dari investasi dimasa lalu.

\section{Metodologi Penelitian}

Penelitian ini merupakan penelitian deskripsi yang menjelaskan suatu gambaran objek dan hasil tertentu. Penelitian ini dengan menggunakan Balance Score Card dengan perspektif keuangan dan diukur oleh rasio permodalan (capital), rasio Kualitas Aktiva Produktif (KAP), rasio rentabilitas (earning), rasio likuiditas (liquidity) dan sensitivitas terhadap resiko pasar (sensitivity to market risk) untuk menganalisis laporan keuangan yang telah dipublikasikan tahun 2016. Penelitian ini mendeskripsikan hasil penilaian kinerja dari perspektif 
keuangan dari Bank Mandiri Syariah, BNI Syariah, BRI Syariah pada tahun 2016.

Jenis data yang digunakan dalam penelitian ini adalah data sekunder dalam bentuk data keuangan Bank Mandiri Syariah, BNI Syariah, BRI Syariah, yang telah dipublikasikan tahun 2016. Sumber data penelitian ini diperoleh dari Direktori Perbankan Indonesia yang diterbitkan oleh Bank Indonesia, dari situs Bursa Efek Indonesia.Teknik pengumpulan data yang digunakan dalam penelitian ini yaitu menggunakan tehnik dokumentasi dari laporan keuangan Bank Mandiri Syariah, BNI Syariah, BRI Syariah tahun 2016.

Teknik yang dipakai dalam menganalisis data adalah analisis kualitatif dengan menggunakan pendekatan deskriptif. Metode deskriptif merupakan penelitian terhadap masalah-masalah yang berupa fakta saat ini dari suatu populasi. ${ }^{12}$ Untuk mengukur kinerja keuangan perusahaan diperlukan rasio keuangan yang signifikan menggambarkan kinerja keuangan. Untuk itu dalam penelitian ini mencoba menggunakan rasio Kualitas Aktiva Produktif (KAP). Kinerja perspektif keuangan ini terdiri dari rasio-rasio keuangan yang sesuai dari laporan keuangan, yaitu:

\section{Rasio Permodalan (solvability)}

Rasio permodalan ini berfungsi untuk mengukur kemampuan bank dalam menyerap kerugian-kerugian yang tidak dapat dihindari lagi serta dapat pula digunakan untuk mengukur besar-kecilnya kekayaan bank tersebut atau kekayaan yang dimiliki oleh para pemegang sahamnya. Untuk menghitung rasio permodalan digunakan Kewajiban Penyediaan Modal Minimum (KPMM). ${ }^{13}$

$$
\mathrm{KPMM}=\frac{\text { Mtier } 1, \text { Mtier } 2, \text { Mtier } 3-\text { Penyertaan }}{A T M R} \times 100
$$

\section{Dimana:}

\footnotetext{
${ }^{12}$ Indriantoro, Nur dan Bambang Supomo.2002. Metode Penelitian Bisnis: Untuk Akuntansi dan. Manajemen. Edisi Pertama. Yogyakarta: BPFE. hal. 26

${ }^{13}$ Bank Indonesia, Tahun 2007.
} 
- M tier1: Modal inti yaitu modal yang disetor secara eektif seperti modal disetor, agio saham dan lain-lain.

- M tier2: Modal pelengkap yaitu modal bank yang terdiri atas modal pinjaman, pinjaman subordinasi, dan cadangan yang dibentuk tidak berasal dari laba (supplementary capital)

- M tier3: Modal pelengkap tambahan yaitu modal bank yang terdiri atas modal pinjaman, pinjaman subordinasi, dan cadangan yang dibentuk tidak berasal dari laba (supplementary capital)

- Penyertaan: Penanaman dana Bank dalam bentuk saham pada perusahaan yang bergerak di bidang keuangan syariah atau jenis transaksi tertentu berdasarkan prinsip syariah yang berakibat bank memiliki atau akan memiliki saham pada perusahaan yang bergerak di bidang keuangan syariah.

- ATMR: Aktiva Tertimbang Menurut Risiko

Kriteria penilaian peringkat:

Peringkat $1=\mathrm{KPMM} \geq 12 \%$

Peringkat $2=9 \% \leq \mathrm{KPMM}<12 \%$

Peringkat $3=8 \% \leq \mathrm{KPMM}<9 \%$

Peringkat $4=6 \%<\mathrm{KPMM}<8 \%$

Peringkat $5=\mathrm{KPMM} \leq 6 \%$

Kriteria penetapan peringkat faktor permodalan:

a. Peringkat 1 , mencerminkan tingkat modal secara signifikan berada lebih tinggi dari ketentuan KPMM yang berlaku dan diperkirakan tetap berada di tingkat ini untuk 12 (dua belas) bulan mendatang.

b. Peringkat 2, mencerminkan tingkat modal berada lebih tinggi dari ketentuan KPMM yang berlaku dan diperkirakan tetap berada di tingkat ini serta membaik dari tingkat saat ini untuk 12 (dua belas) bulan mendatang. 
c. Peringkat 3, mencerminkan tingkat modal berada sedikit diatas atau sesuai dengan ketentuan KPMM yang berlaku dan diperkirakan tetap berada pada tingkat ini selama 12 (dua belas) bulan mendatang.

d. Peringkat 4, mencerminkan tingkat modal sedikit dibawah ketentuan KPMM yang berlaku dan diperkirakan mengalami perbaikan dalam 6 (enam) bulan mendatang.

e. Peringkat 5, mencerminkan tingkat modal berada lebih rendah dari ketentuan.

\section{Rasio Kualitas Aktiva Produktif (KAP)}

Rasio KAP digunakan untuk mengetahui kualitas aktiva produktif, yaitu penanaman dana bank dalam rupiah atau valuta asing dalam bentuk kredit, surat berharga, penempatan pada bank lain dan penyertaan. Penilaian tersebut dilakukan untuk melihat apakah aktiva produktif digunakan untuk menghasikan laba secara maksimal. Selain itu penilaian kualitas aset dimaksudkan untuk menilai kondisi aset bank, termasuk antisipasi atas risiko gagal bayar dari pembiayaan (credit risk) yang akan muncul. Rasio KAP dihitung dengan rumus:

$$
\mathrm{KAP}=\frac{\text { PPAPyangterbentuk }}{\text { PPAPyangwajibdibentuk }} \times 100 \%
$$

Kriteria penetapan peringkat faktor kualitas aset produktif:

a. Peringkat 1, mencerminkan kualitas aset sangat baik dengan risiko portofolio yang sangat minimal.

b. Peringkat 2, mencerminkan kualitas aset baik namun terdapat kelemahan yang tidak signifikan.

c. Peringkat 3, mencerminkan kualitas aset cukup baik namun diperkirakan akan mengalami penurunan apabila tidak dilakukan perbaikan. 
d. Peringkat 4, mencerminkan kualitas aset kurang baik dan diperkirakan akan mengancam kelangsungan hidup bank apabila tidak dilakukan perbaikan secara mendasar.

e. Peringkat 5, mencerminkan kualitas aset tidak baik dan diperkirakan kelangsungan hidup bank sulit untuk dapat diselamatkan.

\section{Rasio Rentabilitas (earning)}

Rasio rentabilitas merupakan alat untuk menganalisis atau mengukur tingkat efisiensi usaha dan kemampuan bank dalam menghasilkan laba. Rasio rentabilitas yang digunakan dalam penelitian ini adalah Net Operational Margin (NOM) dan Beban Operasional Terhadap Pendapatan Operasional (BOPO).

$$
\mathrm{NOM}=\frac{(P O-D B H)-B O}{\text { Rata-rataAP }}
$$

Dimana:

- NOM: Net Operating Margin

- PO: Pendapatan Operasional

- DBH: Distribusi Bagi Hasil

- BO: Biaya Operasional

- Rata-rata Aktiva Produktif: merupakan rata-rata aktiva produktif 12 bulan terakhir.

Kriteria penilaian peringkat:

a. Peringkat $1=\mathrm{NOM}>3 \%$

b. Peringkat $2=2 \%<\mathrm{NOM} \leq 3 \%$

c. Peringkat $3=1,5 \%<\mathrm{NOM} \leq 2 \%$

d. Peringkat $4=1 \%<\mathrm{NOM} \leq 1,5 \%$

e. Peringkat $5=\mathrm{NOM} \leq 1 \%$ 
Sedangkan Beban Operasional Terhadap Pendapatan Operasional (BOPO) digunakan untuk mengukur kemampuan manajemen lembaga keuangan dalam mengendalikan biaya operasional terhadap pendapatan operasional.

$$
\mathrm{BOPO}=\frac{\text { BebanOperasional }}{\text { PendapatanOperasional }} \times 100 \%
$$

Kriteria penetapan peringkat faktor rentabilitas:

a. Peringkat 1, mencerminkan kemampuan rentabilitas sangat tinggi untuk mengantisipasi potensi kerugian dan meningkatkan modal.

b. Peringkat 2, mencerminkan kemampuan rentabilitas tinggi untuk mengantisipasi potensi kerugian dan meningkatkan modal.

c. Peringkat 3, mencerminkan kemampuan rentabilitas cukup tinggi untuk mengantisipasi potensi kerugian dan meningkatkan modal.

d. Peringkat 4, mencerminkan kemampuan rentabilitas rendah untuk mengantisipasi potensi kerugian dan meningkatkan modal.

e. Peringkat 5 , mencerminkan kemampuan rentabilitas sangat rendah untuk mengantisipasi potensi kerugian dan meningkatkan modal.

\section{Rasio Likuiditas (liquidity)}

Rasio likuiditas digunakan untuk menganalisis kemampuan bank dalam memenuhi kewajiban-kewajibannya. Suatu bank dinyatakan likuid apabila bank tersebut dapat memenuhi kewajiban hutangnya, dapat membayar kembali semua simpanan nasabah, serta dapat memenuhi permintaan kredit yang diajukan tanpa terjadi penangguhan. Dalam penelitian ini, rasio likuiditas yang digunakan adalah Loan to Deposit Ratio (LDR) dan Short Term Mismatch (STM).

a. Loan to Deposit Ratio (LDR)

Rasio ini digunakan untuk menilai likuiditas suatu bank yang dengan cara membagi jumlah kredit yang diberikan oleh bank terhadap dana pihak ketiga. Semakin tinggi rasio ini, semakin rendahnya kemampuan 
likuiditas bank yang bersangkutan sehingga kemungkinan suatu bank dalam kondisi bermasalah akan semakin besar.

$$
\mathrm{LDR}=\frac{\text { JumlahKreditYangDibebankan }}{\text { TotalDanaPihakKetiga }} \times 100 \%
$$

b. STM

STM merupakan rasio utama yang berfungsi untuk mengukur kemampuan bank dalam memenuhi kebutuhan likuiditas jangka pendek.

$$
\mathrm{STM}=\frac{\text { Aktiva Jangka Pendek }}{\text { Kewajiban Jangka Pendek }}
$$

Dimana:

- STM: Short Term Mismatch

- Aktiva Jangka Pendek: aktiva likuid kurang dari 3 bulan selain kas, SWBI dan Surat Berharga Syariah Negara (SBSN).

- Kewajiban Jangka Pendek: kewajiban likuid kurang dari 3 bulan

Kriteria penilaian peringkat:
a. Peringkat $1=\mathrm{STM}>25 \%$
b. Peringkat $2=20 \%<\mathrm{STM} \leq 25 \%$
c. Peringkat $3=15 \%<\mathrm{STM} \leq 20 \%$
d. Peringkat $4=10 \%<$ STM $\leq 15 \%$
e. Peringkat $5=\mathrm{STM} \leq 10 \%$

Kriteria penetapan peringkat faktor likuiditas:

a. Peringkat 1, mencerminkan kemampuan likuiditas bank untuk mengantisipasi kebutuhan likuiditas dan penerapan manajemen risiko likuiditas sangat kuat.

b. Peringkat 2, mencerminkan kemampuan likuiditas bank untuk mengantisipasi kebutuhan likuiditas dan penerapan manajemen risiko likuiditas kuat. 
c. Peringkat 3, mencerminkan kemampuan likuiditas bank untuk mengantisipasi kebutuhan likuiditas dan penerapan manajemen risiko likuiditas memadai.

d. Peringkat 4, mencerminkan kemampuan likuiditas bank untuk mengantisipasi kebutuhan likuiditas dan penerapan manajemen risiko likuiditas lemah.

e. Peringkat 5, mencerminkan kemampuan likuiditas bank untuk mengantisipasi kebutuhan likuiditas dan penerapan manajemen risiko likuiditas sangat lemah.

\section{Rasio sensitivitas terhadap resiko pasar (sensitivity to market risk)}

Penilaian sensitivitas atas risiko pasar dimaksudkan untuk menilai kemampuan keuangan bank dalam mengantisipasi perubahan risiko pasar yang disebabkan oleh pergerakan nilai tukar. Penilaian sensitivitas atas risiko pasar dilakukan dengan menilai besarnya kelebihan modal yang digunakan untuk menutup risiko bank dibandingkan dengan besarnya risiko kerugian yang timbul dari pengaruh perubahan risiko pasar (Bank Indonesia, 2007)..

$$
\mathrm{MR}=\frac{\text { Ekses modal }}{\text { Potential loss nilai tukar }}
$$

Dimana:

- MR: Market Risk

- Ekses Modal: kelebihan atas modal minimum yang ditetapkan untuk mengcover risiko pasar akibat pergerakan nilai tukar.

- Potential Loss Nilai Tukar: risiko kerugian yang timbul akibat pergerakan nilai tukar yang berlawanan dengan perkiraan bank (gap position dari exposure banking book valas dikali fluktuasi nilai tukar).

Kriteria penilaian peringkat:

a. Peringkat $1=\mathrm{MR} \cdot 12 \%$ 
b. Peringkat $2=10 \% \cdot \mathrm{MR}<12 \%$

c. Peringkat $3=8 \% \cdot \mathrm{MR}<10 \%$

d. Peringkat $4=6 \% \cdot M R<8 \%$

e. Peringkat $5=\mathrm{MR}<6 \%$

Kriteria penetapan peringkat faktor sensitivitas terhadap risiko pasar:

a. Peringkat 1, mencerminkan risiko sangat rendah, dan penerapan manajemen risiko pasar efektif dan konsisten.

b. Peringkat 2, mencerminkan risiko relatif rendah, dan penerapan manajemen risiko pasar efektif dan konsisten.

c. Peringkat 3, mencerminkan risiko moderat atau tinggi, dan penerapan manajemen risiko pasar efektif dan konsisten

d. Peringkat 4, mencerminkan risiko moderat atau tinggi, dan penerapan manajemen risiko pasar yang kurang efektif dan kurang konsisten.

e. Peringkat 5, mencerminkan risiko moderat atau tinggi, dan penerapan manajemen risiko pasar tidak efektif dan tidak konsisten.

Proses penilaian peringkat kinerja keuangan dilaksanakan dengan pembobotan atas nilai peringkat faktor permodalan, kualitas aset, rentabilitas, likuiditas, dan sensitivitas terhadap risiko pasar.

Tabel 2. Bobot Penilaian Kinerja Keuangan

\begin{tabular}{|l|c|}
\hline \multicolumn{1}{|c|}{ Rasio } & Bobot \\
\hline Peringkat Permodalan & $25 \%$ \\
\hline Peringkat Kualitas Aktiva Produktif & $50 \%$ \\
\hline Peringkat Rentabilitas & $10 \%$ \\
\hline Peringkat Likuiditas & $10 \%$ \\
\hline Peringkat Sensitivitas Terhadap Resiko Pasar & $5 \%$ \\
\hline
\end{tabular}

Sumber : Lampiran Surat Edaran No. 9/24/DPbS Perihal Sistem Penilaian Tingkat Kinerja Keuangan Bank Umum Berdasarkan Prinsip Syariah 
Peringkat faktor keuangan ditetapkan dalam 5 (lima) peringkat sebagai berikut: ${ }^{14}$

a. Peringkat 1, mencerminkan bahwa kondisi keuangan bank atau Unit Usaha Syariah (UUS) tergolong sangat baik dalam mendukung perkembangan usaha dan mengantisipasi perubahan kondisi perekonomian dan industri keuangan.

b. Peringkat 2, mencerminkan bahwa kondisi keuangan bank atau Unit Usaha Syariah (UUS) tergolong baik dalam mendukung perkembangan usaha dan mengantisipasi perubahan kondisi perekonomian dan industri keuangan.

c. Peringkat 3, mencerminkan bahwa kondisi keuangan bank atau Unit Usaha Syariah (UUS) tergolong cukup baik dalam mendukung perkembangan usaha namun masih rentan/lemah dalam mengantisipasi risiko akibat perubahan kondisi perekonomian dan industri keuangan.

d. Peringkat 4, mencerminkan bahwa kondisi keuangan bank atau Unit Usaha Syariah (UUS) tergolong kurang baik dan sensitif terhadap perubahan kondisi perekonomian dan industri keuangan.

e. Peringkat 5, mencerminkan bahwa kondisi keuangan bank atau Unit Usaha Syariah (UUS) yang buruk dan sangat sensitif terhadap pengaruh negatif kondisi perekonomian, serta industri keuangan.

\section{HASIL PENELITIAN}

\section{a. Perbandingan Kinerja BRI Syariah, BNI Syariah dan Bank Syariah}

\section{Mandiri}

Kinerja BRI Syariah, BNI Syariah dan Bank Mandiri Syariah dijelaskan pada Tabel 3 berikut:

${ }^{14}$ Lampiran Surat Edaran No. 9/24/DPbS Perihal Sistem Penilaian Tingkat Kinerja Keuangan Bank Umum Berdasarkan Prinsip Syariah 
Tabel 3. Penilaian Kinerja BRI Syariah Tahun 2016

\begin{tabular}{|l|c|c|c|c|}
\hline \multicolumn{1}{|c|}{ Faktor } & $\begin{array}{c}\text { Uraian/ } \\
\text { Rasio }\end{array}$ & BRI Syariah & $\begin{array}{c}\text { BNI } \\
\text { Syariah }\end{array}$ & $\begin{array}{c}\text { BSM } \\
\text { Syariah }\end{array}$ \\
\hline Permodalan & KPMM & $20,62 \%$ & $27,68 \%$ & $12,46 \%$ \\
\hline $\begin{array}{l}\text { Kualitas Aktiva } \\
\text { Produktif }\end{array}$ & KAP & $100 \%$ & $99 \%$ & $99 \%$ \\
\hline \multirow{2}{*}{ Rentabilitas } & NOM & $7,50 \%$ & $5,07 \%$ & $6,23 \%$ \\
\cline { 2 - 5 } & BOPO & $98,77 \%$ & $88,05 \%$ & $73,15 \%$ \\
\hline \multirow{2}{*}{$\begin{array}{l}\text { Likuiditas } \\
\text { Sensitivitas risiko } \\
\text { pasar }\end{array}$} & $\begin{array}{l}\text { Sensitivitas } \\
\text { Terhadap } \\
\text { Risiko Pasar }\end{array}$ & $95,82 \%$ & $62,02 \%$ & $85,16 \%$ \\
\hline
\end{tabular}

Sumber: diolah

Berdasarkan hasil perbandingan kinerja BRI Syariah, BNI Syariah dan Bank Mandiri Syariah dijelaskan sebagai berikut:

\section{Rasio Permodalan}

Berdasarkan Tabel 3 dapat dibandingkan kinerja bank dilihat dari rasio modal (KPMM) dari ketiga bank syariah yaitu BRI Syariah, BNI Syariah dan Bank Mandiri Syariah. Rasio KPMM dari BRI Syariah 20,62\%, BNI Syariah 27,68\% dan Bank Mandiri Syariah 12,46\% menunjukkan bahwa berdasarkan rasio permodalan tertinggi adalah BNI Syariah sedangkan nilai rasio permodalan terendah oleh BRI Syariah.

Berdasarkan hasil analisis perbandingan tersebut dapat dikaji bahwa BNI Syariah memiliki rasio permodalan yang tertinggi. Hal itu diakibatkan dengan adanya perluasan usaha dan pembiayaan BNI Syariah lebih baik diantara kedua bank syariah yang lain yaitu BRI Syariah dan Bank Mandiri 
Syariah. Perluasan usaha dan pembiayaan dapat membuat modal bank semakin tinggi dikarenakan semakin meningkatkanya dana yang akan diterima BNI Syariah nantinya.

\section{Rasio KAP}

Berdasarkan hasil analisis kinerja bank diukur dengan rasio KAP menunjukkan bahwa BRI Syariah pada tahun 2016 memiliki tingkat KAP sebesar 100\% sedangkan BNI Syariah dan Bank Mandiri Syariah pada tahun 2016 memiliki tingkat KAP sebesar 99\%. BRI Syariah memiliki rasio KAP paling tinggi diantara BNI Syariah dan Bank Mandiri Syariah berarti cadangan aktiva produktif yang dibentuk oleh BNI Syariah guna mengantisipasi kemungkinan tidak tertagihnya kembali penanaman modal atau alokasi dana yang telah dilakukan bank ke dalam aktiva produktif.

Berdasarkan perbandingan nilai KAP ketiga bank menunjukkan bahwa BRI Syariah memiliki KAP yang tertinggi. Hal tu menunjukkan bahwa BRI Syariah memiliki kemampuan untuk memperoleh laba maksimal dari kualitas aktiva produktif, yaitu penanaman dana bank dalam rupiah atau valuta asing dalam bentuk kredit, surat berharga, penempatan pada bank lain dan penyertaan. Selain itu, BRI Syariah mampu mengantisipasi risiko gagal bayar (risiko kredit) yang akan muncul nantinya daripada bank BNI Syariah dan Bank Mandiri Syariah.

\section{Rasio Rentabilitas}

Rentabilitas menunjukkan kemampuan bank untuk menghasikan laba yang merupakan tujuan jangka panjang setiap usaha.Rasio yang digunakan untuk mengukur rentabilitas dalam penelitian ini adalah Net Operational Margin (NOM) dan BOPO.

1. Rasio NOM 
Nilai NOM pada BRI Syariah sebesar 7,50\%. Sedangkan NOM BNI Syariah 5,07\% dan Bank Syariah Mandiri 6,23\%. Hasil analisis kinerja menunjukkan bahwa berdasarkan rasio NOM tertinggi adalah BRI Syariah sedangkan nilai rasio NOM terendah oleh BNI Syariah. Hal ini berarti kemampuan memperoleh laba BRI Syariah paling baik sehingga pembagian keuntungan juga paling baik diantara BNI Syariah dan Bank Mandiri Syariah. Hal itu dikarenakan perluasan usaha BRI Syariah disegala unit daerah dapat memberikan keunggulan dalam memperoleh keuntungan bank nantinya.

\section{Rasio BOPO}

Rasio BOPO adalah perbandingan antara biaya operasional dengan pendapatan operasional. BOPO tertinggi terjadi pada BRI Syariah yaitu sebesar 98,77\%, BNI Syariah yaitu sebesar 88,05\% dan Bank Mandiri Syariah yaitu sebesar 73,15\%. Hasil analisis kinerja menunjukkan bahwa berdasarkan rasio BOPO tertinggi adalah BRI Syariah sedangkan nilai rasio BOPO terendah oleh BNI Syariah. Hal itu menunjukkan bahwa BRI Syariah memiliki kemampuan perolehan laba yang terbaik dikarenakan BRI Syariah mampu melakukan efisiensi biaya dan perolehan keuntungan yang lebih besar diantara kedua bank lainnya. Sedangkan pada BNI Syariah memiliki efisiensi biaya operasional paling rendah diantara BRI Syariah dan Bank Mandiri Syariah.

\section{Rasio Likuiditas (Liquidity)}

Penilaian likuiditas dimaksudkan untuk memastikan dilaksanakannya manajemen aset dan kewajiban dalam menentukan dan menyediakan likuiditas yang cukup. Pada umumnya manajemen kurang menyukai penggunaan benchmark tertentu untuk rasio likuiditasnya.Walaupun begitu, perusahaan pada umumnya kekurangan liquid assets segera sebelum episode kepailitan terjadi dan biasanya perusahaan tersebut meminjam lebih banyak 
lagi untuk mengelola kewajiban jangka pendeknya. Aspek likuiditas diukur dengan menggunakan rasio Loan Deposit Ratio (LDR) dan STM.

1. LDR

LDR adalah rasio keuangan perusahaan perbankan yang berhubungan dengan aspek likuiditas. LDR BRI Syariah yaitu sebesar 95,82\%; BNI Syariah yaitu sebesar 62,02\% dan Bank Mandiri Syariah yaitu sebesar $85,16 \%$. Hal itu menunjukkan bahwa BRI Syariah paling besar dalam penyaluran dana bentuk kredit dibandingkan dengan deposit atau simpanan masyarakat pada suatu bank membawa konsekuensi semakin besarnya risiko yang harus ditanggung oleh bank yang bersangkutan.

2. Short Term Mismatch (STM)

STM merupakan rasio utama yang berfungsi untuk mengukur kemampuan bank dalam memenuhi kebutuhan likuiditas jangka pendek. Short Term Mismatch (STM) BRI Syariah ada tahun 2016 yaitu sebesar 84,09\%, BNI Syariah ada tahun 2016 sebesar 24,70\% dan Bank Mandiri Syariah sebesar 32,38\% pada tahun 2016. Hal ini mencerminkan bahwa kemampuan likuiditas bank untuk mengantisipasi kebutuhan likuiditas dan penerapan manajemen risiko likuiditas sangat kuat. Hasil analisis kinerja menunjukkan bahwa berdasarkan rasio STM tertinggi adalah BRI Syariah sedangkan nilai rasio STM terendah oleh BNI Syariah. Hal ini dikarenakan kewajiban jangka pendek bisa lebih dipenuhi oleh aktiva jangka pendek BRI Syariah dibandingkan kedua bank syariah lainnya yaitu BNI Syariah dan Bank Mandiri Syariah.

\section{Rasio Sensitivitas Pasar}

Hasil perhitungan rasio ini pada BRI Syariah pada tahun 2016 memiliki tingkat sensitifitas pasar risiko pasar sebesar 7\%, BNI Syariah sebesar 5\% dan Bank Mandiri Syariah pada tahun 2016 memiliki tingkat sensitifitas pasar risiko pasar sebesar $1 \%$. Hasil analisis kinerja menunjukkan bahwa 
berdasarkan rasio sensitivitas pasar tertinggi adalah BRI Syariah sedangkan nilai rasio sensitivitas pasar terendah oleh BNI Syariah.

\section{E. PEMBAHASAN}

Hasil analisis rasio keuangan pada ketiga bank syariah yaitu BRI Syariah, BNI Syariah dan Bank Mandiri Syariah. Penilaian dilakukan dengan rasio permodalan (capital), rasio Kualitas Aktiva Produktif (KAP), rasio rentabilitas (earning), rasio likuiditas (liquidity) dan sensitivitas terhadap risiko pasar (sensitivity to market risk).

Penilaian kinerja pada BRI Syariah berdasarkan perspektif keuangan yang diukur dengan rasio KPPM (permodalan), KAP, NOM dan BOPO (rentabilitas), LDR dan STM (Likuiditas) dan sensitivitas pasar menunjukkan bahwa kinerja BRI Syariah tergolong baik. Hal itu berarti pengelolaan dari segala aspek keuangan baik permodalan, likuiditas, rentabilitas dan risiko pasar BRI Syariah telah memenuhi kriteria yang ditetapkan dalam penilaian kinerja bank. Demikian juga kinerja BNI Syariah dan Bank Syariah Mandiri secara keseluruhan juga tergolong baik. Berdasarkan perbandingan kinerja dari ketiga bank syariah yaitu BRI Syariah, BNI Syariah dan Bank Mandiri Syariah pada umumnya adalah BRI Syariah kecuali rasio permodalan yang memiliki nilai tertinggi adalah BNI Syariah.

Rasio permodalan tertinggi adalah BNI Syariah sedangkan nilai rasio permodalan terendah oleh BRI Syariah. BNI Syariah memiliki rasio KPMM tertinggi disebabkan BNI Syariah mampu lebih baik dalam pengelolaan modal yang baik dan melakukan perluasan usaha dan pembiayaan yang lebih tinggi sehingga permodalan BNI Syariah lebih tinggi dibandingkan dengan permodalan yang dimiliki BRI Syariah dan Bank Mandiri Syariah.Berdasarkan hasil analisis kinerja bank diukur dengan rasio KAP menunjukkan bahwa BRI Syariah memiliki rasio KAP paling tinggi diantara BNI Syariah dan Bank 
Mandiri Syariah. Hal itu berarti cadangan aktiva produktif yang dibentuk oleh BNI Syariah guna mengantisipasi kemungkinan tidak tertagihnya kembali penanaman modal atau alokasi dana yang telah dilakukan bank ke dalam aktiva produktif paling baik dibandingkan BNI Syariah dan Bank Mandiri Syariah. Semakin tinggi rasio KAP suatu bank, maka kemungkinan bank mengalami kesulitan keuangan semakin kecil sebab kualitas aset bank yang bersangkutan tergolong semakin baik dan dengan risiko portofolio yang sangat minimal. Baiknya kualitas aset tersebut memberikan informasi bahwa kebijakan dan prosedur pemberian pembiayaan dan pengelolaan risiko dari pembiayaan bank yang bersangkutan telah dilaksanakan dengan baik, sesuai dengan skala usaha bank, dan kondisi kegiatan operasional yang dilakukan berada pada level yang aman dan sehat. Sebaliknya, semakin buruk atau kecil rasio KAP pada suatu bank, maka dapat dimaknai bahwa pada bank tersebut terdapat kelemahan yang sangat signifikan dan kemungkinan bank mengalami kesulitan keuangan akan semakin besar, dan kesulitan keuangan tersebut berpotensi mengancam kelangsungan hidup bank. Sebab, kelangsungan usaha bank tergantung dari kemampuan dalam melakukan penanaman dana dengan mempertimbangkan risiko dan prinsip kehati-hatian berupa pemenuhan kualitas aktiva dan penyisihan penghapusan aktiva yang memadai.

Rasio NOM tertinggi diperoleh oleh pada BRI Syariah dan terendah oleh BNI Syariah. Hal ini menunjukkan bahwa kemampuan laba BRI Syariah paling baik. Semakin tinggi rasio NOM suatu bank, maka kemungkinan bank mengalami kesulitan keuangan semakin kecil. Sebab, kemampuan rentabilitas bank untuk mengantisipasi potensi kerugian dan meningkatkan modal juga semakin besar. Sebaliknya, semakin buruk atau kecil rasio NOM pada suatu bank, dapat dimaknai bahwa pada bank tersebut terdapat kelemahan dalam mengantisipasi potensi kerugian dan kelemahan dalam meningkatkan modal, sehingga kemungkinan bank mengalami kesulitan keuangan akan semakin besar. 
Hasil analisis kinerja menunjukkan bahwa berdasarkan rasio BOPO tertinggi adalah BRI Syariah, sedangkan nilai rasio BOPO terendah oleh BNI Syariah. Hal itu menunjukkan bahwa BNI Syariah memiliki kinerja efisiensi terhadap kemampuan perolehan laba yang terbaik bagi bank. Semakin kecil rasio ini, akan semakin baik bagi bank. Hal tersebut berarti semakin efisien biaya operasional yang dikeluarkan bank yang bersangkutan sehingga kemungkinan suatu bank dalam kondisi bermasalah yang mengarah pada kesulitan keuangan semakin kecil. Sebaliknya, semakin tinggi rasio ini, mengindikasikan kurangnya kemampuan efisiensi biaya operasional yang dikeluarkan bank yang bersangkutan sehingga kemungkinan suatu bank dalam kondisi kesulitan keuangan semakin besar

Berdasarkan rasio LDR menunjukan bahwa BRI Syariah paling besar dalam penyaluran dana bentuk kredit dibandingkan dengan deposit atau simpanan masyarakat pada suatu bank membawa konsekuensi semakin besarnya risiko yang harus ditanggung oleh bank yang bersangkutan. Sedangkan rasio STM tertinggi adalah BRI Syariah sedangkan nilai rasio STM terendah oleh BNI Syariah. Hal ini mencerminkan bahwa kemampuan likuiditas bank untuk mengantisipasi kebutuhan likuiditas dan penerapan manajemen risiko likuiditas sangat kuat. Berdasarkan kriteria penilaian peringkat kesehatan STM di atas, dalam kerangka teoretik ini dapat dirumuskan bahwa semakin tinggi rasio STM suatu bank maka kemungkinan bank mengalami kesulitan keuangan semakin kecil. Sebab, kemampuan likuiditas bank untuk mengantisipasi kebutuhan likuiditas dan penerapan manajemen risiko likuiditas juga semakin besar. Sebaliknya, semakin buruk atau kecil rasio STM pada suatu bank, dapat dimaknai bahwa pada bank tersebut terdapat kelemahan dalam manajemen likuiditas bank untuk mengantisipasi kebutuhan likuiditas dan penerapan manajemen risiko likuiditas, sehingga kemungkinan bank mengalami kesulitan keuangan akan semakin besar. 
Hasil perhitungan rasio sensitivitas pasar tertinggi adalah BRI Syariah sedangkan nilai rasio sensitivitas pasar terendah oleh BNI Syariah. Hal itu berarti BRI Syariah memiliki kemampuan mengatasi atau meminimalkan risiko akibat fluktuasi suku bunga paling baik diantara BNI Syariah dan Bank Mandiri Syariah.

Rasio rentabilitas yang diukur dengan kemampuan manajemen mengelola pendapatan dilakukan dengan rasio NOM. Penilaian NOM dari BRI Syariah masih tergolong baik karena nilai rasio lebih dari 13\%. Demikian juga dengan BNI Syariah dan Bank Mandiri Syariah. Aspek likuiditas memegang peranan penting dalam tingkat kinerja bank. Salah satu ukuran aspek likuiditas yaitu dengan LDR dan STM. Hasil analisis menunjukkan bahwa LDR BRI Syariah, BNI Syariah dan Bank Mandiri Syariah termasuk peringkat satu yang tergolong baik.

Berdasarkan hasil analisis data maka dapat dijelaskan bahwa ketiga bank syariah antara lain BRI Syariah, BNI Syariah dan Bank Mandiri Syariah tergolong bank yang memiliki kinerja baik. Perbandingan antara ketiga bank tersebut menunjukkan bahwa BRI Syariah merupakan bank yang paling baik dengan peringkat satu. Hal ini menunjukkan kondisi keuangan BRI Syariah tergolong sangat kuat dalam mendukung perkembangan usaha dan mengantisipasi perubahan kondisi perekonomian dan industri keuangan

\section{F. KESIMPULAN DAN SARAN}

Berdasarkan hasil analisis kinerja bank Balancae Score Carddengan perspektif keuangan, dapat disimpulkan bahwa BRI Syariah, BNI Syariah dan Bank Mandiri Syariah memiliki kinerja yang baik tahun 2016.

a. Rasio permodalan (capital), Rasio Kualitas Aktiva Produktif (KAP), Rasio Rentabilitas (earning), Rasio Likuiditas (liquidity) dan Sensitivitas terhadap resiko pasar (sensitivity to market risk) pada BRI Syariah tergolong baik. 
b. Rasio permodalan (capital), Rasio Kualitas Aktiva Produktif (KAP), Rasio Rentabilitas (earning), Rasio Likuiditas (liquidity) dan Sensitivitas terhadap resiko pasar (sensitivity to market risk) pada BNI Syariah tergolong baik.

c. Rasio permodalan (capital), Rasio Kualitas Aktiva Produktif (KAP), Rasio Rentabilitas (earning), Rasio Likuiditas (liquidity) dan Sensitivitas terhadap resiko pasar (sensitivity to market risk) pada Bank Mandiri Syariah tergolong baik.

d. Berdasarkan hasil perbandingan rasio permodalan (capital), Rasio Kualitas Aktiva Produktif (KAP), Rasio Rentabilitas (earning), Rasio Likuiditas (liquidity) dan Sensitivitas terhadap resiko pasar (sensitivity to market risk) pada Bank Mandiri Syariah, BNI Syariah dan BRI Syariah maka pada umumnya rasio yang terbesar adalah rasio BRI Syariah kecuali rasio permodalan, kedua BNI Syariah kecuali rasio likuiditas dan ketiga BSM kecuali sensitivitas pasar.

Berdasarkan kesimpulan tersebut maka dapat disarankan hal-hal sebagai berikut.

a. Bagi bank, BNI Syariah, BRI Syariah dan Bank Mandiri Syariah untuk mengevaluasi kinerja bank, khususnya yang berkaitan dengan tingkat kinerja bank terutama dalam kemampuan memperoleh laba dan menekan biaya operasional. Dalam meningkatkan laba maka dapat dilakukan dengan meningkatkan kepercayaan nasabah, memperluas wilayah pemasaran dan melakukan efisisensi pada biaya operasional. Selain itu juga dilakukan pengelolaan syariah yang optimal untuk meningkatkan keuntungan. Untuk BRI Syariah hendaknya meningkatkan pengelolaan modal bank, BNI Syariah meningkatkan likuditas dan Bank Mandiri Syariah meningkatkan rasio sensitivitas pasar dengan mengelola modal dan antisipasi terhadap suku bunga. 
Reka Meilani

b. Bagi peneliti selanjutnya hendaknya menambah sampel penelitian dengan pembanding bank umum konvensional serta melakukan penilaian tingkat kinerja bank dengan menggunakan metode lain. Selain itu periode penelitian diperpanjang atau ditambah agar memperoleh hasil yang dapat dibandingkan dengan kinerja tahun sebelumnya. 


\section{DAFTAR PUSTAKA}

Antonio, Muhammad Syafi'i. 2005. Bank Syariah: Wacana Ulama dan Cendekiawan. Jakarta: Bank Indonesia.

Ascarya. 2005. Akad dan Produk Bank Syariah. Jakarta: PT Raja Grafindo Persada.

Istiqlal, Chayo Halim. 2009. Penilaian Kinerja Perbankan Syariah Dengan Metode Balanced Scorecard. Jurnal Ekonomi Islam Volume 2 Desember.

Indriantoro, Nur dan Bambang Supomo. 2002. Metode Penelitian Bisnis: Untuk Akuntansi dan. Manajemen. Edisi Pertama. Yogyakarta: BPFE.

Kaplan, Robbert S. dan David P. Norton. 2001. The Strategy Focused Organizations: How Balanced Scorecard Companies Thrive in The New Business Environment. Boston: Harvard Business School Press.

Kasmir. 2004. Bank dan Lembaga Keuangan Lainnya. Jakarta : PT Raja Grafindo Persada.

Lampiran Surat Edaran No. 9/24/DPbS Perihal Sistem Penilaian Tingkat Kinerja Keuangan Bank Umum Berdasarkan Prinsip Syariah.

Lampiran Surat Edaran No. 9/24/DPbS Perihal Sistem Penilaian Tingkat Kinerja Keuangan Bank Umum Berdasarkan Prinsip Syariah.

Mulyadi. 2001. Balanced Scorecard: alat Manajemen Kontemporer Untuk Pelipatganda Kinerja Keuangan Perusahaan. Jakarta: Salemba Empat.

Peraturan Bank Indonesia, Tahun 2007.

Rhamadana, Recly Bima. 2016. Analisis Rasio Keuangan Untuk Menilai Kinerja Keuangan Pada PT H.M. Sampoerna Tbk. Jurnal Ilmu dan Riset Manajemen. Volume 5, No. 7.

www.ojk.go.id 